\title{
ACUTE NONOLIGURIC RENAL FAILURE ASSOCIATED WITH NAPROXEN SODIUM IN A CHILD
}

\author{
COCUKTA NAPROKSEN SODYUM KULLANIMINA BAĞLI \\ AKUT NONOLIGURIK BÖBREK YETMEZLIĞGi
}

Hakan ERDOĞAN

Dildar Bahar GENC

Ayşe ERDOGAN

Gülçin BAŞDEMIR

\section{SUMMARY}

Non-steroidal anti-inflammatory drug (NSAID) associated nephrotoxicity is uncommon during childhood in contrast to higher incidence in adults.

A 12-year-old previously healthy boy was admitted to hospital with abdominal pain after ingestion of $275 \mathrm{mg}$ of Naproxen bid for three days to relieve toothache. His physical examination was within normal limits except dental caries at left first premolar tooth. Erythrocyte sedimentation rate was $65 \mathrm{~mm} /$ hour and urine analysis showed $(+)$ proteinuria and 8-10 erythrocytes with normal blood biochemistry. At fifth day of admission, his urea and creatinine levels increased to $85 \mathrm{mg} / \mathrm{dL}$ and $4 \mathrm{mg} / \mathrm{dL}$, respectively. Consecutively, he developed persistent microscopic hematuria and proteinuria of $12 \mathrm{mg} / \mathrm{m}^{2} / \mathrm{hour}$. During his hospitalization, blood pressure remained stable and urine output was normal. A renal ultrasound demonstrated increased echogenicity of kidneys and percutaneous renal biopsy revealed tubulointerstitial nephritis. He was conservatively treated with intravenous hydration and supportive care. Renal function gradually returned to normal within 14 days.

The popularity of NSAIDs continues to grow among physicians for pediatric use and many children use some form of NSAIDs on unprescribed basis. However, they can lead to severe nephrotoxicity even at therapeutic doses in healthy children. Although reported cases of naproxen induced renal failure are very few, appropriate precautions should be taken while treating children with naproxen.

Key words: Acute renal failure, naproxen use in children.

\section{ÖZET}

Anti-inflamatuvar kullanımına bağlı renal toksitite erişkin yaş grubunda sık görülmesine rağmen çocukluk yaş grubunda nadirdir.

Diş ağrısı sebebiyle 3 gün süreyle günde 2 defa 275 mg naproksen sodyum kullanan 12 yaşındaki erkek olgu karın ağrısı sebebiyle hastaneye başvurdu. Olgunun başvuru sırasında fizik bakı bulguları sol 1. premolar dișteki çürük dıșında normaldi. Başlangıçta eritrosit sedimentasyon hızı $65 \mathrm{~mm} / \mathrm{saat}$, idrarda $(+)$ protein ve mikroskopisinde ise 8-10 eritrosit dişında böbrek

\author{
Cocuk Nefroloji Kliniği, Bursa Dörtçelik Çocuk Hastanesi, Bursa \\ (Uz. Dr. H. Erdoğan) \\ Çocuk Onkoloji Kliniği \\ (Uz. Dr. D. B. Genç) \\ Farmakoloji Bölümü, Sevket Yılmaz Eğitim ve Araştırma Hastanesi, Bursa, Turkey \\ (Uz. Dr. A. Erdoğan) \\ Patoloji Lab, Acibadem Hastanesi, Bursa \\ (Uz. Dr. G. Başdemir) \\ İletişim: Uz. Dr. Hakan Erdogan
}


fonksiyon testleri normaldi. Yatıșının 5. gününde üre $85 \mathrm{mg} / \mathrm{dl}$, kreatinin $4 \mathrm{mg} / \mathrm{dl}$ olarak saptandı. Bu dönemde mikroskopik hematüri ve $12 \mathrm{mg} / \mathrm{m}^{2} /$ saat proteinüri vardı. Kan basıncı normal seyretti. İdrar çıkışı başlangıçtan itibaren yeterli olan olgunun böbrek ultrasonunda ekojenite artışı saptandı. Perkütan renal biyopside akut interstisyel nefrit saptanan hastaya intravenöz sıvı desteği uygulandı. Böbrek fonksiyon testleri 14 gün içinde aşamalı olarak normale döndü.

Çocukluk yaş grubunda kullanımı giderek artan steroid olmayan anti-inflamatuvar ilaçların tedavi dozlarında bile nefrotoksik olabileceği unutulmamalıdır. Çocuklarda naproksen kullanımına bağlı çok az sayıda olgu bildirilmiştir. Tüm steroid olmayan anti-inflamatuvar ilaçlar gibi, naproksen da çocukluk yaş grubunda dikkatli kullanılmalıdır.

Anahtar Sözcükler: Akut böbrek yetmezliği, çocukta naproksen kullanımı

\section{INTRODUCTION}

Non-steroidal anti-inflammatory drugs (NSAIDs) have potentially serious side effects including kidney, skin, hematological and central nervous system but their most common side effect occurs at the gastrointestinal level. The effects of NSAIDs on the kidneys are increasingly recognized. Frequency of renal side effects was reported to range between $1-5 \%$ (1). Renal sequale include mild side effects like hyperkalemia, salt and water retention besides acute renal failure (ARF) being the most serious one. Acute hemodynamic changes and acute interstitial nephritis (AIN) are the major pathogenetic factors inducing ARF. However, underlying renal disease and dehydration increase the susceptibility to NSAID related nephrotoxicity (2). Most cases of ARF associated with NSAID usage are mild and resolve spontaneously (3).

Naproxen has similar pharmacological properties to other NSAIDs. Rheumatic diseases are the major indication for naproxen prescription during childhood in addition to treatment of inflammation and mild to moderate pain in children older than 12 years. In contrast to adults, very few pediatric cases of ARF secondary to naproxen administration have been reported $(4,5)$. Here, we present a case of biopsy proven AIN leading to ARF induced by Naproxen at therapeutic dosage.

\section{CASE REPORT}

A 12-year-old previously healthy boy was admitted to hospital with abdominal pain after he ingested $275 \mathrm{mg}$ Naproxen bid for three days to relieve his toothache. Personal and family history were unremarkable. His physical examination was normal except dental caries at left first premolar tooth. His blood pressure was approriate for age height and gender and there was neither weight gain nor edema. Initial laboratory work-up revealed whole blood count, liver enzymes, electrolytes and renal function tests as normal. Erythrocyte sedimentation rate was $65 \mathrm{~mm} /$ hour and urine analysis showed $(+)$ proteinuria with 8-10 erythorcytes. Intravenous fluid of $2000 \mathrm{ml} / \mathrm{m}^{2} /$ day and lansoprozole of $15 \mathrm{mg} /$ day were given in order to overcome renal and gastrointestinal side effects. Microscopic hematuria and proteinuria persisted. As urea and creatinine levels increased after 2 days, intravenous fluid was increased to $3000 \mathrm{ml} / \mathrm{m}^{2} /$ day and lansoprozole was stopped. At fifth day of admission, urea, creatinine and uric acid levels were $85 \mathrm{mg} / \mathrm{dl}, 4 \mathrm{mg} / \mathrm{dl}$ and $12 \mathrm{mg} / \mathrm{dl}$, respectively (Table 1). Electrolytes, complement levels $\left(\mathrm{C}_{3}\right.$ and $\mathrm{C}_{4}$ ), whole blood count, arterial blood gas and antistreptolysin $\mathrm{O}$ titer were normal while rheumatoid factor, dsDNA and antinuclear antibodies were negative. Abdominal pain rapidly resolved and neither abnormal physical examination findings nor hypertension were observed during follow-up. Daily urinalysis revealed proteinuria (1+), a specific gravity of 1015 , nitrite negativity and 8-10 erythrocytes without eosinophiluria. Urine culture was sterile. 24-hour urine sample showed proteinuria of $10-12 \mathrm{mg} / \mathrm{m}^{2} /$ hour. Renal ultrasound was normal except increased echogenecity of both kidneys. Urine output was normal as 2$3 \mathrm{ml} / \mathrm{kg} /$ hour through disease course. A percutaneous kidney biopsy was performed secondary to microscopic hematuria, nephritic proteinuria and gradual deterioration of renal function.

Light microscopy of renal specimen demonstrated AIN (Figure 1). Fourteen glomeruli were observed in biopsy specimen with no sign of sclerosis and infiltration. Massive interstitial infiltration with lymphocytes, plasma cells and neutrophils was noted. The vasculature was regular in structure. Immunofluorescence examination was interpreted as normal. Starting from $7^{\text {th }}$ day of intravenous hydration, renal function and urine abnormality gradually improved and totally recovered at $14^{\text {th }}$ day. The patient was discharged at $15^{\text {th }}$ day. At his first - and second -month visits after hospitalization, he was perfectly normal in terms of physical examination findings and laboratory results. 
Table 1. Laboratory investigations during follow-up

\begin{tabular}{lcccccc}
\hline & Day 1 & Day 3 & Day 5 & Day 7 & Day 10 & Day 14 \\
\hline Urea $(\mathrm{mg} / \mathrm{dl})$ & 18 & 67 & 85 & 74 & 55 & 31 \\
Creatinine $(\mathrm{mg} / \mathrm{dl})$ & 0,8 & 3,2 & 4 & 3,8 & 1,8 & 0,8 \\
Uric acid $(\mathrm{mg} / \mathrm{dl})$ & 5 & 9 & 12 & 9 & 5 & 6 \\
Leukocyte $\left(/ \mathrm{mm}^{3}\right)$ & 8500 & 9100 & & 10000 & 9500 & 5600 \\
Hematocrit $(\%)$ & 34 & 35 & & 33 & 33 & 36 \\
ESR* $(\mathrm{mm} /$ hour) & 65 & & 98 & & 85 & 29 \\
Specific gravity & 1020 & 1015 & 1015 & 1020 & 1020 & 1015 \\
Proteinuria(dipstick) & $1+$ & $1+$ & $1+$ & $1+$ & - & - \\
Urinalysis & $4-5 \mathrm{RBC} * *$ & $10-15 \mathrm{RBC}$ & $10-15 \mathrm{RBC}$ & $5-10 \mathrm{RBC}$ & Normal & Normal \\
Proteinuria*** $\left(\mathrm{mg} / \mathrm{m}^{2} /\right.$ hour & & 12 & 10 & 6 & 4 & 3 \\
\hline
\end{tabular}

*ESR: Erythrocyte sedimentation rate, ${ }^{* *}$ RBC: Red blood cell, ${ }^{* * *}$ Quantitative measurement

Table 2. Previous case reports of naproxen toxicity

\begin{tabular}{cccccccc}
\hline Reference & Age* $^{*}$ & $\begin{array}{c}\text { Naproxen } \\
\text { Taken for }\end{array}$ & $\begin{array}{c}\text { Duration of } \\
\text { Therapy }\end{array}$ & Extra NSAID** $^{*}$ & Biopsy & Treatment & Outcome \\
\hline 3 & 6 & Arthritis & 1 week & $\varnothing$ & AIN & $\begin{array}{c}\text { Oral prednisolone } \\
\text { Recovery }\end{array}$ \\
4 & 10 & JRA $^{\S}$ & 1 month & Diclofenak & AIN* & $\begin{array}{c}3 \text { doses HDMP } \text { pral }^{+} \text {prednisolone } \\
\text { Recovery }\end{array}$ \\
5 & 2 & JRA & 1 month & $\varnothing$ & AIN & Intravenous hydration & Recovery \\
7 & 14 & IBD & 2 months & ASA $^{* * *+T o l m e t i n ~}$ & AIN & Oral prednisolone & ESRD* \\
10 & 14 & Dysmenorrhea & 5 days & Rofecoxib & AIN & Intravenous hydration & Recovery \\
Our Case & 12 & Toothache & 3 days & $\varnothing$ & AIN & Intravenous hydration & Recovery \\
\hline
\end{tabular}

* Age: Years, ${ }^{\S}$ JRA: Juvenile Rheumatoid Arthritis,

** NSAID: Additional Nonsteroidal anti-inflammatory drug ingested by the patient,

*** ASA: Acetylsalicylic acid, ${ }^{+}$High dose methylprednisolone, ${ }^{\#}$ IBD: Inflammatory bowel disease

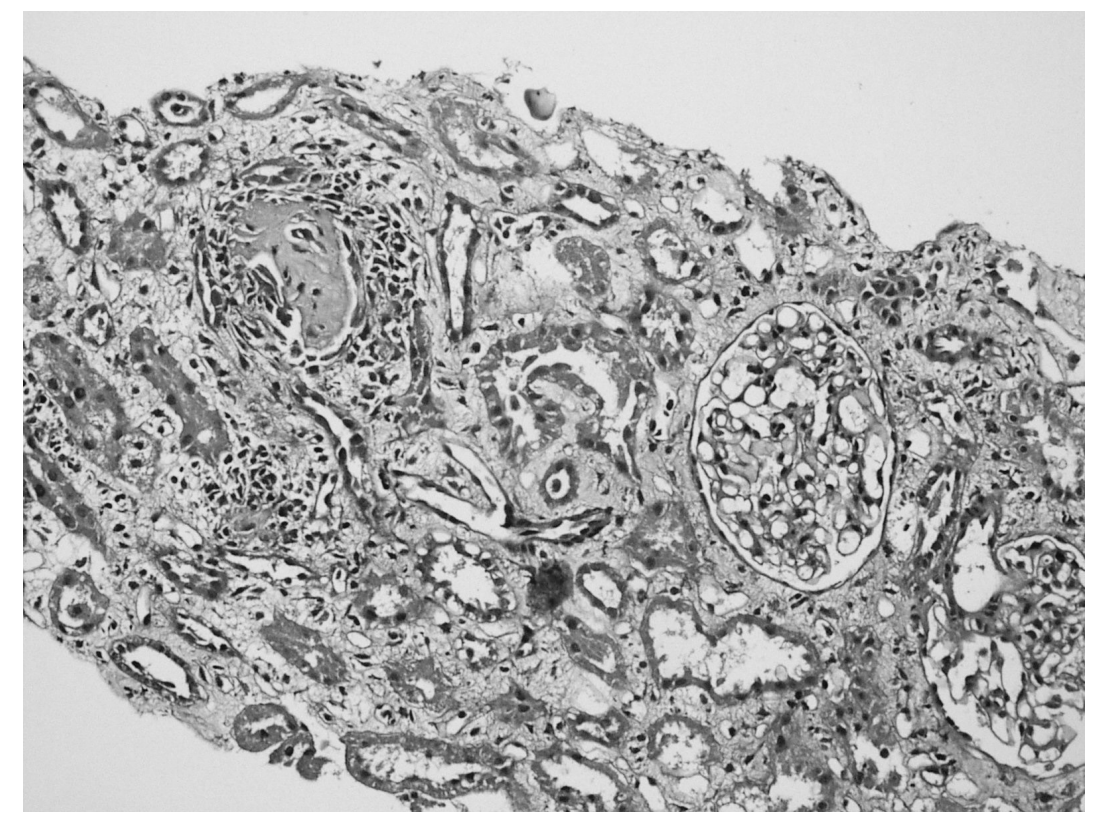

Figure 1. Tubules widely separated by interstitial edema and inflammatory infiltration composed predominantly of lymphocytes and plasma cells (Hematoxylin-eosin x 25). 


\section{DISCUSSION}

We here report a 12-year-old boy who developed AIN related acute renal failure secondary to naproxen intake for toothache. We observed that the renal failure had resolved without any specific treatment except for intravenous fluids and withdrawal of naproxen.

There are two main mechanisms by which NSAIDinduced kidney injury may occur: First mechanism is the hemodynamic injury secondary to inhibition of cyclooxygenase (COX) enzyme. As well known, COX produces several leukotrienes and prostaglandin molecules from arachidonnic acid, a cellular membrane lipid. Cyclooxygenase-1 (COX-1) enzyme creates prostaglandins with physiological functions like prostacyclin $\left(\mathrm{PGI}_{2}\right) . \mathrm{PGI}_{2}$ is antithrombotic, protective for gastric mucosa and prevents atherosclerosis at endothelium. COX-2 on the other hand, produces cytokines leading to inflammatory response. Antiinflammatory action and side effects of NSAIDs occurs by inhibition of COX-2 and COX-1, respectively (6). Prostaglandin synthesis inhibition which has a detrimental effect on renal blood flow with consequent ARF is mediated by COX-1 inhibition.

Second mechanism of the nephropathy associated with NSAIDs use is AIN, which can lead to impairment in renal function and nephrotic syndrome or both $(3,5,7)$. This immune-mediated entity can present at variable lengths of time after initiating NSAID treatment. Various antigens and drugs usually acting as haptens causes T-cell activation which starts renal injury (8). Ten to $25 \%$ of adult ARF cases are caused by AIN which in fact is a rare epidemiologic factor of pediatric ARF (8). The reason for this difference is not clear yet. A possible explanation might be the fact that majority of NSAID associated ARF cases rapidly resolves and does not necessitate kidney biopsy which leads to underestimation of real incidence. Clinical findings of AIN are highly protean. Increase in urea and creatinine levels is commonly observed besides fever, rash, eosinophilia and eosinophiluria (9). The distinct feature of NSAID associated AIN is that either nephrotic syndrome or renal failure can be the sole manifestastion without accompanying fever, eosinophilia and eosinophiluria. Occasionally, both clinical pictures coexist (3). Our patient did not present with any remarkable clinical finding or eosinophilia/eosinophiluria. However, his renal function rapidly deteriorated with consecutive development of microscopic hematuria and nephritic range proteinuria. Although NSAID associated ARF was reported to be self-resolving in nature (3), more severe cases requiring steroid treatment were also described in current literature $(3,4,7)$. Thus, a renal biopsy was done in order to confirm the diagnosis and predict prognostic outcome.

Acute renal failure cases due to Naproxen induced AIN are very rare in children. Only 5 biopsy proven cases have been reported in current literature to date $(3,4,5,7,10)$ (Table 2). Of these cases, only one patient developed terminal renal failure which was interpreted to be secondary to underlying inflammatory bowel disease. At second month of naproxen treatment, ARF secondary to AIN was observed. Despite naproxen withdrawal and intervention with corticosteroids, the patient developed end stage renal disease (ESRD) after 18 months of follow-up. Repetitive renal biopsies did not demonstrate glomerular involvement attributable to inflammatory bowel disease but chronicity of AIN (7).

Corticosteroid treatment has been recommended in the treatment of severe AIN cases in adults. In terms of pediatric publications of NSAID associated AIN, 2 more cases of corticosteroid usage were reported besides first case described above $(3,4)$. First patient described by Robinson et al. had nephrotic syndrome after naproxen usage and biopsy showed AIN and effacement of podocyte foot processes at glomeruli. The patient responded well to corticosteroid therapy prescibed particularly for nephrotic syndrome (3). The other case was a juvenile rheumatoid arthritis patient who had naproxen associated AIN. Three doses of high dose methylprednisolone were given and therapy was continued with oral prednisolone which resulted in full recovery of patient (4). The remaining cases underwent spontaneous remission like our patient did (5).

In conclusion, we recommend that naproxen sodium should not be prescribed as a first choice drug to treat pediatric pain and inflammation. For professionals taking care of children, it is probably safer to reserve this potentially hazardous and effective medication for rheumatic diseases.

\section{REFERENCES}

1. DeMaria AN, Weir MR. Coxibs beyond the GI tract: renal and cardiovascular issues. J Pain Symptom Manage 2003;25:41-9

2. Deepak K Malhotra, William I Henrich. Nephropathies of the nonsteroidal antiinflammatory agents. In:Massry SG,Glassock RJ. Textbook of Nephrology. Lippincott Williams \& Wilkins. 2001: 921-5 
3. Robinson J, Malleson P, Lirenman D, Carter J. Nephrotic syndrome associated with nonsteroidal anti-inflammatory drug use in two children. Pediatrics 1990; 85(5): 844-7

4. Becker-Cohen R, Frishberg Y. Severe reversible renal failure due to naproxen-associated acute interstitial nephritis. Eur $J$ Pediatr 2001;160(5):293-5

5. Ray PE, Rigolizzo D, Wara DR, Piel CF. Naproxen nephrotoxicity in a 2-year-old child. Am J Dis Child 1988; 142(5): 524-5

6. Fackovcova D, Kristova V, Kriska M. Renal damage induced by the treatment with non-opioid analgesics--theoretical assumption or clinical significance. Bratisl Lek Listy. 2000; 101(8): 417-2
7. Laxer RM, Silverman ED, Balfe JW, Poucell S, Baumal R. Naproxen-associated renal failure in a child with arthritis and inflammatory bowel disease. Pediatrics 1987; 80(6): 904-8

8. Mc Rea Dell K, Kaplan BS, Meyers CM. Tubulointerstitial Nephritis. In: Barrat TM, Avner ED, Harmon WE (eds). Pediatric Nephrology 4th edn. Lippincott Williams \& Wilkins.1999 : 823-34

9. Greising J, Trachtman H, Gauthier B, Valderrama E. Acute interstitial nephritis in adolescents and young adults. Child Nephrol Urol 1990; 10(4): 189-95

10. Fletcher TJ, Graf N,Scarman A, Saleh H, Alexander IS, Nephrotoxicity with cyclooxygenase 2 inhibitor use in children. Pediatr Nephrol 2006; 21: 1893-97

\section{CORRESPONDENCE TO}

Dr. Hakan Erdogan

Address: Dortcelik Children Hospital, Department of Pediatric Nephrology

Ozluce-Nilufer-Bursa-TURKEY

E-mail: drerdoganha@yahoo.com

Phone: +90 2244511009

+905326969035 